\title{
EVALUASI PROGRAM PEMBERDAYAAN MASYARAKAT MENURUT UNDANG-UNDANG NOMOR 6 TAHUN 2014 (STUDI KASUS PROGRAM DESA MAJU INHIL JAYA DI DESA DANAU PULAI INDAH DAN DESA KARYA TANI KECAMATAN KEMPAS (KABUPATEN INDRAGIRI HILIR)
}

\author{
Muhammad April ${ }^{1}$, Muammar Alkadafi, ${ }^{2}$ \\ 1,Dosen Hukum Program studi D3 Administrasi Perpajakan, 2, Dosen Administrasi Pemerintahan Daerah \\ Program Studi S1 Ilmu Adminstrasi Negara, Fakultas Ekonomi dan Ilmu Sosial, Universitas Islam Negeri \\ Sultan Syarif Kasim Riau, Pekanbaru.
}

Email: muhammad.april@uin-suska.ac.id / muamar@uin-suska.ac.id (korespondensi)

\begin{abstract}
The Integrated Village of Inhil Jaya (DMIJ) Plus Program, is the flagship program of the Government of Indragiri Hilir Regency. This research is to find out the implementation of the Integrated Maju Inhil Jaya Plus Village (DMIJ) program, the impact of the implementation and the constraints of the Integrated DMIJ Plus program in Danau Pulai Indah Village and Karya Tani Village. The research method used a qualitative research approach, with evaluative research types by case studies. Sources of data obtained through observation, documents, and in-depth interviews (indepth interview), with key informants; Village Heads, Village Officials, BPD, LKMD, community leaders and community group representatives. The results of the study, showed that the implementation of the Maju Inhil Jaya Village program in Danau Pulai Indah Village and Karya Tani Village covered 4 (four) fields of activities that were not fully implemented, the program implementation was still conservative-involutive. The integrated DMIJ Plus program has a positive impact on the field of village governance, the field of village development, and the field of village community development can also be said to be good. while the field of village community empowerment, the desired results have not been good or less than the maximum. The impact of the DMIJ program has not been fully felt by the community, the contribution of the program is still minimal in the field of community empowerment. The constraints are the still limited quality of the human resources of the program implementers, and the program target communities.
\end{abstract}

Keywords: Public Policy, Policy Evaluation, Development and Empowerment.

\begin{abstract}
Abstrak
Program Desa Maju Inhil Jaya (DMIJ) Plus Terintegrasi, merupakan program unggulan Pemerintah Kabupaten Indragiri Hilir. Penelitian ini untuk mengetahui pelaksanaan program Desa Maju Inhil Jaya Plus Terintegrasi (DMIJ), dampak pelaksanaan dan kendala program DMIJ Plus Terintegrasi di Desa Danau Pulai Indah dan Desa Karya Tani. Metode Penelitian menggunakan pendekatan penelitian kualitatif, dengan jenis penelitian evaluatif dengan studi kasus. Sumber data diperoleh melalui observasi, dokumen, dan wawancara mendalam (indepth interview), dengan key informan; Kepala Desa, Perangkat Desa, BPD, LKMD, tokoh masyarakat dan perwakilan kelompok masyarakat. Hasil penelitian, menunjukkan bahwa Pelaksanaan program Desa Maju Inhil Jaya di Desa Danau Pulai Indah dan Desa Karya Tani mencakup 4 (empat) bidang kegiatan belum sepenuhnya terlaksana dengan baik, pelaksanaan program masih bersifat konservatif-involutif. Program DMIJ Plus terintegrasi berdampak positif pada bidang penyelenggaraan pemerintahan desa, bidang pembangunan desa, dan bidang pembinaan kemasyarakatan desa juga dapat dikatakan baik. sementara bidang pemberdayaan masyarakat desa, hasil yang diinginkan belum baik atau kurang maksimal. Dampak dari program DMIJ belum sepenuhnya dirasakan masyarakat, kontribusi program masih minim dalam bidang pemberdayaan masyarakat. Kendala masih terbatasnya kualitas sumber daya manusia para pelaku implementor program, masyarakat sasaran program.
\end{abstract}

Kata kunci: Kebijakan Publik, Evaluasi Kebijakan, Pembangunan dan Pemberdayaan 


\section{PENDAHULUAN}

Kabupaten Indragiri Hilir adalah salah satu Kabupaten dari 12 Kabupaten/Kota di Provinsi Riau yang berdiri berdasarkan Undang-Undang Nomor 6 tahun 1965. Memiliki luas wilayah $18.812,24 \mathrm{~km}^{2}$ dengan daratan seluas $11.605,97 \mathrm{~km}^{2}$ dari daratan tersebut, 10,740,16 km² merupakan dataran berawa dan dipengaruhi oleh pasang surut. Secara administratif kabupaten ini terdiri atas 20 Kecamatan 216 Desa dan Kelurahan, dengan rincian 198 Desa dan 18 Kelurahan dengan pusat Pemerintahan berada di Kota Tembilahan. Kabupaten ini juga memiliki banyak potensi sumber daya alam, perkebunan kelapa yang sangat luas. Tapi data BPS menunjukkan angka kemiskinan masih cukup tinggi, angka pengangguran terbuka mencapai $45,13 \%$ dari 612.127 angkatan kerja. Untuk menekan angka kemiskinan ini, maka pembangunan insfrastruktur yang menunjang roda perekonomian menjadi prioritas utama disamping menggunakan pendekatan multi disiplin yang berdimensi pemberdayaan.

Berdasarkan data Kementerian PDT dan Transmigrasi tahun 2016, tentang indeks desa membangun, dengan memberikan status dan kriteria desa di Indonesia. Adapun status dan kriteria desa-desa di Kabupaten Indragiri Hilir adalah berstatus: a. sangat tertinggal $63(31,81 \%)$, b. tertinggal $111(56,06 \%)$, c. berkembang 24 $(12,12 \%)$, d. Maju 0, e. Mandiri 0. Data tersebut menunjukkan bahwa 174 (88\%), desa di Kabupaten Indragiri Hilir tergolong tertinggal. (Permendes PDT dan

Transmigrasi, 2016)

Badan Pusat Statistik Kabupaten Indragiri Hilir pada tahun 2017 menyebut jumlah penduduk miskin di Kabupaten Indragiri Hilir mencapai 55.400 jiwa $(7,70 \%)$, dari jumlah penduduk 703.734. Masalah kemiskinan selama ini didasarkan pada asumsi bahwa kemiskinan merupakan fenomena rendahnya kesejahteraan dan kurangnya penguasaan terhadap sumber daya. Padahal sebenarnya fenomena kemiskinan sangat kompleks dan bersifat multidimensional. Masalah kemiskinan ditandai oleh banyak faktor: misalnya kerentanan, ketidakberdayaan, tertutupnya akses kepada berbagai peluang kerja, kondisi fisik yang lemah akibat kurangnya gizi, tingginya tingkat ketergantungan mereka dan terefleksikannya dalam budaya kemiskinan yang digariskan satu generasi ke generasi berikutnya. Kemiskinan itu sendiri bukanlah hal yang melekat pada diri orang miskin itu sendiri seperti ketidakberdayaan, kerawanan, kelemahan fisik, isolasi dan kemiskinan itu sendiri, dan dapat pula merupakan sesuatu yang bersifat eksternal seperti kebijaksanaan pembangunan yang lebih mendukung perkembangan lapisan masyarakat ekonomi kuat ketimbang lapisan masyarakat lemah.

Rendahnya kapasitas pemerintahan desa dan masyarakat desa dalam mengelola pembangunan perlu di segera ditindaklanjuti dengan suatu program pemberdayaan masyarakat desa. Dengan disahkannya Undang-Undang Nomor 6 Tahun 2014 tentang Desa dan Peraturan Pemerintah Republik Indonesia Nomor 43 Tahun 2014 tentang Peraturan pelaksanaan UndangUndang Nomor 6 Tahun 2014 Tentang Desa, diperlukan penguatan secara sistematis kelembagaan yang ada untuk menjalankan kebijakan pemerintah pusat dan daerah di tingkat kabupaten, kecamatan dan desa.

Upaya mempercepat pembangunan, khususnya di pedesaan erat kaitannya dengan partisipasi masyarakat dan kemandirian desa. Partisipasi masyarakat ini dimulai dari perumusan persoalan, perencanaan, pengelolaan, pengendalian kegiatan dan penilaian keberhasilan pembangunan. Dengan partisipasi ini diharapkan masyarakat pada akhirnya memiliki kemampuan membangun dirinya sendiri dan lingkungannya secara swadaya dan berkelanjutan. Swadaya masyarakat merupakan semangat untuk membebaskan diri dari ketergantungan pada pihak luar atau kekuatan dari atas dengan memanfaatkan sumberdaya yang mereka miliki. Swadaya masyarakat juga dapat dipahami sebagai kemampuan untuk memanfaatkan dan mengembangkan fasilitas-fasililtas yang telah tersedia sebagai hasil pembangunan yang dilaksanakan pemerintah.

Dalam rangka percepatan pembangunan dan untuk menekan angka kemiskinan tersebut pembangunan infrastruktur yang menunjang perekonomian menjadi prioritas utama pembangunan di Kabupaten Indragiri Hilir terutama di daerah pedesaan. Menurut Ishak Shari (2000), masalah kemiskinan dan pendapatan rendah masih merupakan masalah yang dihadapi oleh masyarakat desa, maka usaha membasmi kemiskinan dan mengurangkan ketidakseimbangan ekonomi perlu juga memikirkan usaha memajukan kawasan desa. Sedangkan menurut Hamsiah Kasimin (1996), pembasmian kemiskinan merupakan salah satu strategi utama yang diberi perhatian oleh pemerintah. Pengentasan kemiskinan merupakan hal yang mutlak 
harus dilakukan. (Salisusiana dan Yulia, 2000:96) menyebut permasalahan yang sebenarnya bukan terletak pada dilakukan atau tidaknya pengentasan kemiskinan itu, namun bagaimana mengentaskan kemiskinan dengan cara yang tepat sehingga memberi hasil yang efisien dan efektiv. Dalam hal ini, diperlukam format yang tepat bagi pengentasan kemiskinan di Indonesia.

Cita-cita pemerintah dengan menerapkan berbagai kebijakan pembangunan, baik itu pembangunan dengan pendekatan pertumbuhan maupun pembangunan dengan pendekatan pemberdayaan (empowerment), semuanya sebagai upaya untuk mengentaskan kemiskinan. Berbagai program-program pemerintah lintas departemen/kementerian, pemerintah daerah, yang dilaksanakan selama ini ialah bertujuan untuk mengentaskan atau mengurangi angka kemiskinan. Teori pembangunan sosial merupakan sumber gagasan (pijakan awal) dari konsep pemberdayaan, bermaksud membangun keberdayaan, yaitu membangun manusia dalam mengatasi permasalahan hidupnya. Birdshall (1993) dalam Rostika (2003:26) memandang pembangunan ekonomi dan pembangunan sosial sebagai dua hal yang terpadu. Pembangunan sosial adalah pembangunan ekonomi, pembangunan sosial adalah keadaan ekonomi yang baik dari suatu masyarakat, tujuan mendasar dari pembangunan ekonomi bukanlah pertumbuhan ekonomi, melainkan kemajuan kesejahteraan manusia, yaitu apa yang sering disebut pembangunan manusia atau pembangunan sosial. Jadi tujuan pembangunan sesungguhnya hanya satu yaitu kesejahteraan manusia. Dengan demikian pembangunan sosial adalah pembangunan manusia itu sendiri.

Pada tahun 2005 Pemerintah Kabupaten Indragiri Hilir mengeluarkan kebijakan Program Desa Mandiri yang fokus pada program pembangunan infrastruktur pedesaan, dan berlangsung hingga akhir tahun 2013. Pada tahun 2014 Pemerintah Kabupaten Indragiri Hilir kembali mengeluarkan kebijakan program Desa Maju Inhil Jaya (DMIJ) sebagai perwujudan janjijanji politik Bupati dan Wakil Bupati terpilih (HM Wardan-Rosman Malomo).

Kebijakan Program DMIJ dilihat dari model dan bentuk pendekatannya, tidak jauh berbeda dengan program desa mandiri, yang dikeluarkan oleh Bupati Inhil $(H$. Indra Mukhlis Adnan) pada tahun 2005. Dalam konteks pendekatan pembangunan dan pemberdayaan yang berbasis bottom-up program DMIJ merupakan keberlanjutan program sebelumnya yaitu program Desa Mandiri, hanya saja program DMIJ yang mempunyai ruang lingkup/cakupan yang lebih luas, karena menyesuaikan dengan ruang lingkup pengelolaan desa dan kewenangan yang diberikan dalam undangudangan nomor 6 tahun 2014 tentang desa.

Program Desa Maju Inhil Jaya (DMIJ) adalah salah satu program prioritas pembangunan Kabupaten Indragiri Hilir sebagaimana telah ditetapkan dalam Perda Nomor 5 Tahun 2014 Tentang RPJMD Kabupaten Indragiri Hilir Tahun 2013-2018. Pada periode kedua kepemipinan Bupati Indragiri Hilir ( $\mathrm{H}$. Wardan) bersama $\mathrm{H}$. Syamsudin Uti periode 2019-2023, dilakukan perubahan strategi penguatan program DMIJ menjadi DMIJ Plus Terintegrasi dalam penguatan pengembangan ekonomi masyarakat desa dan kawasan perdesaan melalui pelembagaan Badan Usaha Milik Desa (BUM Desa). Implementasi Dana Program DMIJ/Plus terintegrasi dalam operasionalisasinya bersumber dari bagi hasil pajak dan retribusi daerah, alokasi dana desa dan bantuan keuangan kepada desa yang berjumlah Rp. 500.000.000,- s.d 900.000.000,-. sasaran program dmij adalah masyarakat desa, kelembagaan masyarakat dan pemerintahan desa.

Program DMIJ dicetuskan menurut Bupati Inhil (HM. Wardan) ialah untuk membuka keterisolasioan antar desa. dan secara spesifik menurut Kepala BPMPD Kabupaten Indragiri Hilir (Yulizal) Program DMIJ dilatarbelakangi dari 1). Semakin terkikisnya semangat gotong royong dan rasa kebersamaan ditengah - tengah masyarakat akibat dari kebijakan yang berorientasi proyek, 2). Masyarakat tidak dilibatkan/masyarakat hanya sebagai obyek, 3). Infrastruktur dan prasarana dasar desa sangat minim, banyak desa relatif tertinggal dan masyarakat miskin relatif tinggi, 4). Aspirasi masyarakat tidak terakomodir dalam APBD, 5). Menurunnya citra pemerintah ditengah-tengah masyarakat, 6). Ekonomi masyarakat pedesaan kurang bergairah karena prasarana dasar kurang tersedia.

Pada dasarnya kebijakan program DMIJ merupakan program yang sangat baik dilihat dari kondisi masyarakat Kabupaten Indragiri Hilir, namun sebuah program yang sedang dilaksanakan tidaklah serta merta dapat berjalan sesuai dengan tujuan dan sasaran yang diinginkan, banyak faktor yang mempengaruhi dalam pelaksanaan suatu 
kebijakan. Untuk itu penting untuk dilakukan suatu evaluasi terhadap implementasi program dalam rangka untuk mengetahui sejauhmana tingkat pencapaian tujuan program yang telah ditargetkan dan direncanakan. Secara umum menurut hemat peneliti, selama ini evaluasi terhadap pelaksanaan program-program pemerintah sangat minim dilakukan terutama untuk melihat sejauhmana sebuah program melahirkan keluaran (output), manfaat (benefits), dan dampak (impact) terhadap kehidupan masyarakat.

Hasil penelitian (Mupid, 2016:89) menyebutkan tingkat partisipasi masyarakat dalam pelaksanaan program DMIJ di Kecamatan Keritang tingkat partisipasinya masih rendah. Implementasi program DMIJ masih mengalami beberapa kendala, penelitian (M.Arif, 2017:11) menyebutkan kendala tersebut yakni; faktor keterbatasan jumlah dana, karena sumber pendanaan Program DMIJ sebahagian besar bersumber dari Alokasi Dana Desa yang jumlahnya $10 \%$ dari total APBD, sementara besaran APBD Kabupaten Indragiri Hilir dari tahun ke tahun mengalami fluktuasi. Selanjutnya faktor masih terbatasnya Sumber Daya Manusia sebahagian perangkat desa dalam menggunakan perangkat teknologi komputer, sehingga masih menjadi faktor penghambat lemahnya pengoperasionalan yang berbasis aplikasi.

Untuk mengetahui keluaran, manfaat dan dampak Program DMIJ terhadap masyarakat, penelitian bermaksud untuk melakukan kajian evaluasi pelaksanaan Program Desa Maju Inhil Jaya (DMIJ) yang dicetuskan/dicanangkan oleh Bupati

Indragiri Hilir periode 2014-2018 dan periode 2019-2023, telah berjalan kurang lebih 6 tahun. Jadi, kajian evaluasi impelementasi terhadap pelaksanaan program DMIJ yang peneliti fokuskan di Desa Danau Pulai Indah, Desa Karya Tani Kecamatan Kempas. Dengan demikian, yang menjadi tujuan penelitia ini adalah:

1. Untuk mengetahui Pelaksanaan program pemberdayaan masyarakat pada program Desa Maju Inhil Jaya (DMIJ) di Desa Danau Pulau Indah dan Desa Karya Tani Kecamatan Kempas Kabupaten Indragiri Hilir.

2. Untuk mengetahui dampak Program Desa Maju Inhil Jaya (DMIJ) terhadap pemerintah desa dan masyarakat desa secara luas, di Desa Danau Pulau Indah dan Desa Karya Tani Kecamatan Kempas Kabupaten Indragiri Hilir.
3. Untuk mengetahui kendala pelaksanaan program pemberdayaan masyarakat pada program Desa Maju Inhil Jaya (DMIJ) di Desa Danau Pulau Indah dan Desa Karya Tani Kecamatan Kempas Kabupaten Indragiri Hilir.

\section{TINJAUAN PUSTAKA}

\subsection{Evaluasi Kebijakan (Policy Evaluation)}

Salah satu aspek penting dalam proses atau tahapan kebijakan publik menurut para ahli (William Dunn, 1994. Ripley, 1985. James Anderson, 1979. Micahael Howlet \& Ramesh, 1995. dalam subarasono, 2005:9-13) adalah tahap evaluasi kebijakan.

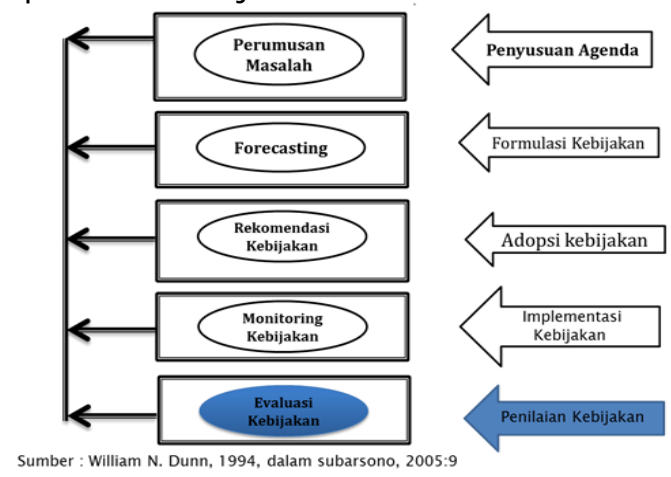

Gambar 1. Prose Kebijakan Publik

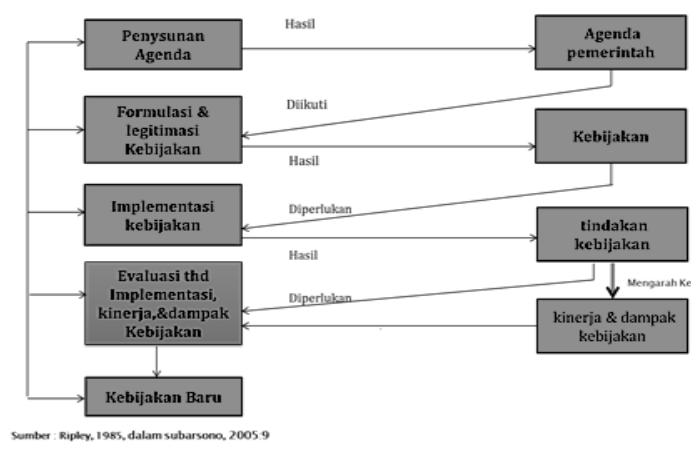

Gambar 2. Tahapan Kebijakan Publik

Evaluasi adalah kegiatan untuk menilai tingkat kinerja suatu kebijakan. Tujuan evaluasi kebijakan ialah. Pertama, menentukan tingkat kinerja suatu kebijakan. Kedua, mengukur tingkat efisiensi suatu kebijakan. Ketiga, mengukur tingkat keluaran (outcome) suatu kebijakan. Keempat, mengukur dampak suatu kebijakan. Keenam, untuk mengetahui apabila ada penyimpangan. Ketujuh, sebagai bahan masukan (input) untuk kebijakan yang akan datang.

Program Desa Maju Inhil Jaya (DMIJ), sebagai sebuah kebijakan, setelah dilakukan tindakan kebijakan, maka akan dihasilkan kinerja dan dampak kebijakan, dan proses 
selanjutnya adalah evaluasi terhadap implementasi, kinerja dan dampak kebijakan tersebut.

Tabel 1. Indikator Evaluasi Kebijakan Program DMIJ.

\begin{tabular}{|c|c|l|}
\hline No & Kriteria & \multicolumn{1}{|c|}{ Penjelasan } \\
\hline 1 & Efektivitas & $\begin{array}{l}\text { Apakah hasil yang } \\
\text { diinginkan telah } \\
\text { tercapai }\end{array}$ \\
\hline 2 & Kecukupan & $\begin{array}{l}\text { Seberapa jauh hasil } \\
\text { yang telah tercapai } \\
\text { dapat memecahkan } \\
\text { masalah }\end{array}$ \\
\hline 3 & Pemerataan & $\begin{array}{l}\text { Apakah biaya dan } \\
\text { manfaat } \\
\text { didistribusikan } \\
\text { merata kepada } \\
\text { kelompok yang } \\
\text { masyarakat } \\
\text { berbeda }\end{array}$ \\
\hline 4 & Responsivitas & $\begin{array}{l}\text { Apakah hasil } \\
\text { kebijakan memuat } \\
\text { preferensi /nilai } \\
\text { kelompok dan dapat } \\
\text { memuaskan mereka }\end{array}$ \\
\hline 5 & Ketepatan & $\begin{array}{l}\text { Apakah hasil yang } \\
\text { dicapai bermanfaat }\end{array}$ \\
\hline
\end{tabular}

Sumber : William Dunn, 1994. Dalam Subarsono 2005: 126

\subsection{Konsep Pembangunan Desa Pemberdayaan Masyarakat Desa}

dan

Konteks pembangunan desa adalah "masyarakat" (Batten , 1957); menyebutkan "satu pergerakan yang dibentuk untuk meningkatkan keadaan kehidupan keseluruhan masyarakat dengan partisipasi aktif mereka, dan kalau bisa dengan inisiatif anggota masyarakat itu sendiri. Sekiranya inisiatif ini tidak muncul, maka teknik-teknik lain akan digunakan oleh pemerintah atau swasta".

Pembangunan Desa adalah upaya peningkatan kualitas hidup dan kehidupan untuk sebesar-besarnya kesejahteraan masyarakat Desa. Sedangkan, Pemberdayaan Masyarakat Desa adalah upaya mengembangkan kemandirian dan kesejahteraan masyarakat dengan meningkatkan pengetahuan, sikap, keterampilan, perilaku, kemampuan, kesadaran, serta memanfaatkan sumber daya melalui penetapan kebijakan, program, kegiatan, dan pendampingan yang sesuai dengan esensi masalah dan prioritas kebutuhan masyarakat Desa (Wahyudin, 2015:18).
Pemberdayaan adalah sebuah proses dan tujuan. Sebagai proses, pemberdayaan adalah serangkaian kegiatan untuk memperkuat kekuasaan atau keberdayaan kelompok lemah dalam masyarakat, termasuk individu-individu yang mengalami masalah kemiskinan. Sebagai tujuan, maka pemberdayaan menunjuk pada keadaan atau hasil yang ingin dicapai oleh sebuah perubahan sosial. (Edi Suharto, 2009:58)

Menurut Sumodiningrat (1997 : 165), pemberdayaan masyarakat bertalian erat dengan upaya penanggulangan masalahmasalah pembangunan, seperti pengangguran, kemiskinan dan kesenjangan. Lebih lanjut, Sumodiningrat mengatakan bahwa pemberdayaan masyarakat bukan membuat masyarakt menjadi makin tergantung kepada programprogram pemberian (charity), karena pada dasarnya setiap apa yang dinikmati harus dihasilkan atas usaha sendiri. Dengan demikian, tujuan akhirnya adalah memandirikan masyarakat dan membangun kemampuan untuk memajukan diri kearah kehidupan yang lebih baik secara berkesinambungan.

Pemberdayaan Masyarakat dalam Konteks UU No 6 Tahun 2014 tentang desa disebutkan bahwa Pemberdayaan masyarakat Desa bertujuan memampukan Desa dalam melakukan aksi bersama sebagai suatu kesatuan tata kelola Pemerintahan Desa, kesatuan tata kelola lembaga kemasyarakatan Desa dan lembaga adat, serta kesatuan tata ekonomi dan lingkungan. (PP 43 Tahun 2015 tentang pelaksana UU No 6 Tentang Desa) Pemberdayaan masyarakat Desa bertujuan memampukan Desa dalam melakukan aksi bersama sebagai suatu kesatuan tata kelola Pemerintahan Desa, kesatuan tata kelola lembaga kemasyarakatan Desa dan lembaga adat, serta kesatuan tata ekonomi dan lingkungan.

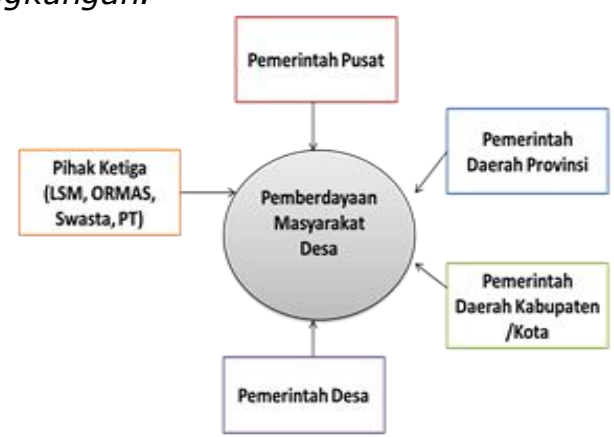

Sumber: Data Olahan dari UU No 6 Tahun 2014 dan PP 43 Tahun 2015

Gambar 3. Pelaku Pemberdayaan Masyarakat Desa 
Pelaku Pemberdayaan Pada Tingkat Desa

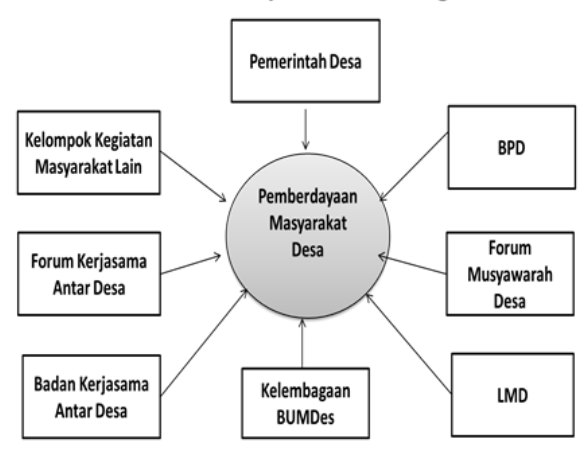

Sumber : Data Olahan : UU No 6 Tahun 2014 dan PP 43 Tahun 2015

Gambar 4. Pelaku Pemberdayaan Pada Tingkat Desa

\subsection{Konsep Desa Membangun Dan Desa Mandiri}

Desa membangun adalah spirit UU No.6 Tahun 2014 Tentang Desa, Desa membangun diarahkan untuk memperkuat upaya memfasilitasi dukungan pemajuan Desa menuju Desa Mandiri. Desa Berkembang, dan terutama Desa Maju, kemampuan mengelola Daya dalam ketahanan sosial, ekonomi, dan ekologi secara berkelanjutan akan membawanya menjadi Desa Mandiri. (Hamidi,dkk.2015:6)

Kemandirian desa secara konseptual identik dengan otonomi desa. Konsep kemandirian desa atau desa mandiri yang diamanatkan UU Desa, dimaknai sebagai dalam pengertian "emansipasi" desa. Emansipasi pada dasarnya berbicara tentang persamaan hak dan pembebasan dari dominasi. Dengan kalimat lain, emansipasi desa berarti desa tidak menjadi obyek imposisi, dominasi dan penerima manfaat proyek, melainkan desa berdiri tegak sebagai subyek pemberi manfaat. Desa bermanfaat melayani kepentingan masyarakat setempat dan bergerak membangun ekonomi termasuk dalam kategori emansipasi itu. (Eko, 2015: 94-98)

\section{Metode Penelitian}

Adapun Jenis penelitian ini adalah penelitian evaluatif dengan pendekatan Deskriptif, Penelitian evaluatif menggunakan kriteria, tolak ukur, atau stándar yang digunakan sebagai pembanding bagi data yang diperoleh, setelah data tersebut diolah dan merupakan kondisi nyata dari objek yang diteliti. Kesenjangan antara kondisi nyata dengan kondisi harapan yang dinyatakan dalam kriteria itulah yang dicari. Dari kesenjangan tersebut diperoleh gambaran apakah objek yang diteliti sudah sesuai, kurang sesuai, atau tidak sesuai dengan kriteria. (Arikunto, 2013:36) Penelitian ini dilaksanakan di desa Desa Danau Pulai Indah dan Desa Karya Tani Kecamatan Kempas Kabupaten Indragiri Hilir. Fokus dalam penelitian ini adalah evaluasi pelaksanaan program kegiatan DMIJ/Plus terintegrasi, Evaluasi dampak program DMIJ DMIJ/Plus terintegrasi, Faktor kendala pelaksanaan. Sumber data diperoleh dari data primer dan data skunder. Prosedur penelitian evaluatif ialah mengidentifikasi komponen dan objek sebagai sebuah sistem. Program DMIJ merupakan sistem kebijakan, maka peneliti menentukan komponen dalam program DMIJ.

\subsection{Komponen Penilaian Kegiatan Program DMIJ di Desa Nusantara Jaya \\ a. Penyelenggaraan Pemerintahan desa \\ b. Pembangunan desa \\ c. Pembinaan kemasyarakatan desa \\ d. Pemberdayaan masyarakat desa}

\subsection{Komponen Penilaian Berdasarkan} Tujuan Program DMIJ

a. Partisipasi Masyarakat

b. Pembangunan Partisipatif, Memberdayakan Masyarakat dan SDA

c. Transparansi dan Akuntabilitas Publik

d. Prakarsa dan partisipasi masyarakat

e. Sarana prasarana pelayanan pemerintahan

f. Penghasilan,insentif aparat desa dan operasional

g. sarana dan prasarana sosial dasar

h. Sinergi pendekataan perencanaan (politis, teknokratik, partisipatif, top down dan buttom up

i. Memaksimalkan peran dan fungsi kelembagaan desa

j. Kapasitas pemerintah desa dan LKD

k. Kapasitas masyarakat

I. Sarana dan prasarana pendukung ekonomi

m. Sarana dan prasarana pendukung pendidikan, sosial keagamaan

n. Sinergi antar program

Data yang diperoleh melalui observasi, indept interview, kuisioner, dan telaah dokumen, berdasarkan komponen kegiatan program DMIJ dan tujuan khusus program DMIJ sebagaiman tercantum dalam tabel. selanjutnya dianalisis secara kualitatif Model Miles dan Humberman (dalam Iskandar, 2009:139), dalam model ini analisis data 
penelitian kualitatif dapat dilakukan melalui langka-langka sebagai berikut: (1) Reduksi Data; (2) Display/penyajan data; dan (3) mengambil kesimpulan lalu diverifikasi.

\section{Hasil dan Pembahasan}

\subsection{Pelaksanaan Program Desa Maju Inhil Jaya}

Program Desa Maju Inhil Jaya adalah program unggulan pemerintah daerah Kabupaten Inhil yang merealisasikan amanat Undang-Undang Nomor 6 Tahun 2015 Tentang Desa yang memiliki konsep salah satunya adalah pemberdayaan masyarakat desa.

Dalam pasal 1 ayat 12 dijelaskan Pemberdayaan Masyarakat Desa adalah upaya mengembangkan kemandirian dan kesejahteraan masyarakat dengan meningkatkan pengetahuan, sikap, keterampilan, perilaku, kemampuan, kesadaran, serta memanfaatkan sumber daya melalui penetapan kebijakan, program, kegiatan, dan pendampingan yang sesuai dengan esensi masalah dan prioritas kebutuhan masyarakat Desa itu. Kemudian dalam pasal 26 ayat 1 Dijelaskan Kepala Desa lah yang memiliki tugas melaksanakan tugas tersebut yaitu bertugas menyelenggarakan Pemerintahan Desa, melaksanakan Pembangunan Desa, pembinaan kemasyarakatan Desa, dan pemberdayaan masyarakat Desa.

Program Desa Maju Inhil Jaya yang disingkat dengan DMIJ adalah program pemberdayaan masyarakat pemerintah daerah Kabupaten Indragiri Hilir yang dikeluarkan melalui Peraturan Daerah Nomor 5 Tahun 2015 Tentang Program Desa Maju Inhil jaya. Dalam perda tersebut dijelaskan tujuan dari DMIJ adalah untuk memberikan jaminan dan kepastiam hukum terhadap hak dan kewajiban setiap orang untuk terlibat dan melibatkan diri dalam proses pengelolaan pembangunan desa. Kemudian dalam BAB II Perda Nomor 5 Tahun 2015 dapat juga disimpulkan bahwa tujuan khusus DMIJ adalah untuk memberikan jaminan peningkatan kapasitas atau peran dan fungsi kelembagan desa, juga tersedianya fasilitas-fasilitas dibidang pembinaan dan pemberdayaan masyarakat desa.

Bentuk keseriusan pemerintah daerah melakukan kebijkaan pemberdayaan masyarakat dalam rangka untuk menekan angka kemiskinan di kabupaten Indragiri Hilir maka dikeluarkan kebijakan dalam bentuk Peraturan Bupati Indragiri Hilir Nomor 6 Tahun 2017 Tentang Petunjuk Teknis Operasional Program Desa Maju
Indaragiri Hilir Jaya. Adapun hasil penelitian evaluasi terhadap pelaksanaan program Desa Maju Inhil Jaya/Plus terintegrasi dalam mewujudkan desa maju dan mandiri di Kabupaten Indragiri Hilir khususnya di Desa Danau Pulai Indah dan Karya Tani Kecamatan Kempas adalah sebagai berikut :

\subsubsection{Penyelenggaraan \\ Pemerintahan Desa}

Tanggapan Masyarakat dari kuesioner dapat diketahui bahwa musyawarah atau rapat-rapat desa dalam penyelenggaraan pemerintahan di Desa Danau Pulai Indah dan desa karya tani telah terlaksana dengan baik. Hal tersebut senada dengan dari kutipan wawancara bapak Mlan (Sekdes) Danau Pulai Indah yang menyebutkan : "Musyawarah desa di Desa Danau Pulai Indah sudah berjalan secara terbuka, kita punya prinsip yang jelas semua perwakilan tokoh masyarakat, kelembagaan desa kita libatkan". Juga sekdes karya tani (Amirudin) mengatakan: "masyarakat selalu dilibatkan dalam musyawarah-musyawarah desa untuk keterbukaan informasi dan mengambil kebiajkan". Musyawarah desa merupakan mekanisme dalam menyepakati keputusan yang bersifat stretegis sebagaimana diatur dalam Permendes No. 2 Tahun 2015 tentang pedoman tata tertib dan mekanisme pengambilan keputusan muswarah desa. Hal tersebut sejalan dengan tujuan dari program DMIJ dalam bidang penyelenggaraan pemerintahan desa agar tercipta partisipasi, demokrasi, transpransi dan akuntabilitas dalam penyelenggaraan pemerintahan desa.

Informasi Desa, di Desa Danau Pulai Indah sudah ada sistem informasi desa yang dibuat (www.danaupulaiindah.desa.id). Namun saat ini tidak bisa diakses karena kendala Domain. Akses masyarakat terhadap informasi desa pada saat ini baru terkait dengan informasi belanja desa dalam APBDes yang bersifat offline, hal tersebut diungkapkan oleh sekretaris desa (Mlan) "informasi desa kita buat dalam bentuk baliho yang kita pajang didepan kantor, berisi tentang belanja desa, sehingga masyarakat bisa mengetahui, namun kalau terkait sistem informasi yang modern kita sudah memiliki memilikinya namun tidak berfungsi karena domain yang habis waktu".

Sementara desa Karya Tani, Informasi desa ditampilkan secara offline menggunakan baliho yang akan dibentangkan dipapan pengumuman kantor desa. Juga hasil wawancara dengan bapak sekdes: "Saat ini desa tidak memiliki system informasi jaringan internet, karena saya rasa belum penting, baliho lebih efektif ketimbang informasi jaringan. Karena 
keterbatasan masyarakat yang belum memahani system komputerisasi".

Sistem Informasi Desa dalam UU No 6 Tahun 2014 Tentang Desa meliputi data Desa, data Pembangunan Desa, Kawasan Perdesaan, serta informasi lain yang berkaitan dengan Pembangunan Desa dan pembangunan Kawasan Perdesaan. Pemerintah dan Pemerintah Daerah wajib mengembangkan sistem informasi Desa dan pembangunan Kawasan Perdesaan. Sistem informasi desa meliputi fasilitas perangkat keras dan perangkat lunak, jaringan, serta sumber daya manusia. Sistem informasi desa dikelola oleh pemerintah desa dan dapat diakses oleh masyarakat desa dan semua pemangku kepentingan.

Kerjasama antar desa. Hasil keterangan sekretaris desa (Bapak Mlan), menyebut "Desa Danau Pulai Indah belum pernah melakukan kerjasama antar desa, baik dalam lingkup di kecamatan Kempas maupun desa diluar kecamatan kempas. Kerjasama antar-desa didalam UU No 6 tahun 2014 tentang desa disebutkan Kerja sama antar-Desa dituangkan dalam Peraturan Bersama Kepala Desa melalui kesepakatan musyawarah antar-Desa. Senada juga disampaikan oleh bapak Amirudin bahwa "sejogjanya kerjasama desa harus terlaksana dengan desa tetangga dalam hal pembangunan jembatan sebagai penghubung antar desa. Namun kerjasama ini tidak terlaksana, sehingga terhambat pembangunan jembatan". Namun disisi lain desa Karya tani memiliki kerjasama dengan pihak ketiga PT. Sinarmas yaitu kebun belajar kelompok tani.

\subsubsection{Pembangunan Desa}

Pelaksanaan pembangunan desa di Desa Danau Pulai Indah melalui program Desa Maju Inhil Jaya pada bidang infrastruktur jalan dan jembatan secara umum terlaksana dengan baik. Keterangan bapak Mlan menyebutkan "kegiatan DMIJ itu kebanyakan pada pembangunan jembatan dan jalan karena itu memang sangat dibutuhkan masyarakat, infrastruktur di desa kami menjadi prioritas untuk diselesaikan karena menjadi masalah utama dalam aktivitas masyarakat."

Bapak Amirudin sekdes Karya Tani mengatakan "Desa sudah merealisasikan dana DMIJ untuk membangun jalan, tapi ada kendala dalam pembangunan jembatan yang menjadi perbatasan dengan desa sebelah, sehingga belum bisa dilaksanakan, seharusnya pembangunan itu dilakukan dalam kerjasama sehingga masyarakat sama-sama bisa menikmati fasilitas pembangunan"

Dari keterangan para informan tersebut, dapat dijelaskan bahwa pembangunan infrastruktur jalan dan jembatan penghubung antara wilayah RT/RW dan dusun sudah terlaksana pada setiap tahun anggaran secara bertahap dan belum disemenisasi, namun hal positif yang dapat menjadi poin penting menurut peneliti adalah masyarakat sudah bisa menikmati fasilitas jalan dan jembatan. Selain pembangunan infrastruktur jalan yang sangat dibutuhkan masyarakat ialah jalan desa, juga akses ke Ibukota Kecamatan dan Kabupaten yang menurut observasi peneliti sedang dikerjakan oleh pemerintah daerah secara bertahap.

Kegiatan pembangunan pada bidang saranan dan prasarana kesehatan seperti sarana air bersih berskala desa dalam bentuk pembangunan sumur Bor disetiap dusun telah terlaksana, setiap rumah tangga mempunyai MCK. juga pada bidang kesehatan ketersediaan sarana dan prasarana kesehatan sudah memadai, aktivitas pelayanan posyandu, dan kepesertaan masyarakat dalam BPJS.

Ketersediaan prasarana pendidikan cukup memadai di kedua desa. Namun dari sisi sarana pendidikan yang belum tercukupi secara baik, hal terebut juga diungkapkan Mlan (Sekdes) menyebutkan" jumlah sekolah pada desa ini saya cukup membantu masyarakat untuk menyekolahkan anaknya, tak perlu jauh-jauh keluar desa, meskipun sekolah-sekolah tersebut fasilitasnya belum lengkap". Senada yang disampaikan oleh sekdes Karya tani (amirudin) : "saat ini kami kekurangan fasilitas sekolah, tetapi pemerintah desa berkomitmen untuk melegkapi secara bertahap melalui dana $D M I J^{\prime \prime}$ Akses terhadap pendidikan formal telah terlaksana, namun yang belum dimiliki dalam wujud pendidikan informal ialah ketersediaan taman bacaan masyarakat atau perpustakaan desa.

Kegiatan pembangunan bidang sarana dan prasarana keamanan dan ketertiban; terdapat poskamling, namun tidak ada partisipasi masyarakat untuk melakukan kegiatan ronda baik di Desa Danau Pulai Indah maupun desa karya tani. Padahal Keamanan dan ketertiban adalah merupakan satu hal yang sangat penting untuk menciptkan rasa aman penduduk.

\subsubsection{Pembinaan Kemasyarakat Desa}

Pembinaan kemasyarakatan desa melalui kegiatan program Desa Maju Inhil Jaya di Kabupaten Indragiri Hilir 
dimaksudkan untuk membiayai kegiatan lembaga-lembaga kemasyarakatan desa. keberadaan lembaga masyarakat sangat diperlukan karena dapat menjadi alat untuk memenuhi kebutuhannya dibidang politik, ekonomi, sosial, budaya dan keamanan. Secara umum pembinaan merupakan upaya perbaikan terhadap pola kehidupan yang direncanakan, Miftah Thoha (2008:207) pembinaan adalah suatu tindakan, proses, hasil dan pernyataan yang lebih baik dalam menunjukkan adanya kemajuan, peningkatan pertumbuhan evolusi atas berbagai kemungkinaan peningkatan atau perkembangan atas sesuatu.

$$
\text { Adapun kegiatan pembinaan }
$$
kemasyarakat desa yang dilaksanakan melalui program DMIJ ialah kegiatan magrib mengaji, pembinaan Posyandu, pembinaan PAUD, pembinaan keagamaan dan ketertiban, pembinaan organisasi PKK, pembinaan KPMD, pembinaan kegiatan hari besar dan HUT RI, pembinaan kemasyarakat organisasi NU.

Namun yang memfokuskan peneliti adalah Kegiatan magrib mengaji yang masuk kedalam Juknis pemberdayaan masyarakat, didesa Danau Pulai indah dan desa karya tani memiliki 1 Unit rumah tahfiz. Sarana ini dibuat adalah bentuk dari keseriusan pemerintah desa dalam melahirkan tahfiz sesuai dengan tujuan pemberdayaan dibidang pembinaan masyarakat desa yaitu "satu rumah satu tahfiz". Jumlah anak-anak yang ikut program ini berjumlah 130 orang dengan jumlah guru 10 orang (danau pulai indah) dan 136 anak dan 7 guru (desa karya tani). dengan memberikan honor Rp. 300.000,perorang setiap bulannya. Hasil wawancara dengan sekdes Desa Danau Pulai Indah (Mlan) menyebutkan " masyarakat sangat antusias memasukkan putera-puterinya ke taman pendidikan Al-Qur'an (TPA) yang ada disetiap mesjid dan surau, apalagi sekarang sudah ada rumah tahfiz yang didirikan oleh pemerintah desa melalui alokasi program DMIJ dengan dana 50.000.000 rupiah dan partisifasi masyarakat (gotong royong) swadaya masyarakat mencapai 100 juta rupiah."

Sedangkan desa karya tani berdasarkan hasil wawancara dengan sekdes desa karya tani bahwa pendirian rumah tahfiz adalah murni dari alokasi dana desa, tanpa adanya partisifasi masyarakat terlibat dalam membangun rumah tahfiz.

Kegiatan posyandu juga terlaksana setiap bulannya di Desa Danau Pulai Indah. Posyandu adalah wadah pemeliharaan kesehatan yang dilakukan dari, oleh dan untuk masyarakat yang dibimbing petugas terkait (Depkes RI, 2006) melalui program DMIJ, setiap kader Posyandu diberikan insentif Rp.100.000-, setiap bulannya.

Kegiatan pembinaan Pendidikan Anak Usia Dini di Desa Danau Pulai Indah. PAUD adalah suatu upaya pembinaan yang dilakukan bagi anak sejak lahir sampai dengan 6 (enam) tahun yang dilakukan pemberian rangsangan, membantu pertumbuhan dan perkembangan jasmani dan rohani anak agar memiliki kesiapan dalam memasuki pendidikan lebih lanjut (UU Sisdiknas No 20 Tahun 2003). Hasil keterangan Mlan menyebutkan " di Desa Danau Pulai Indah terdapat 2 (dua) PAUD, satu dikelola desa, satu lagi milik penduduk setempat, semua PAUD tersebut berjalan dengan baik".

Kegiatan pembinaan organisasi Pemberdayaan dan Kesejahteraan Keluarga (PKK) adalah gerakan nasional dalam pembangunan masyarakat yang tumbuh dari bawah yang pengelolaannya dari, oleh dan untuk masyarakat, menuju terwujudnya keluarga yang beriman dan bertaqwa kepada Tuhan Yang Maha Esa, berakhlak mulia, dan berbudi luhur, sehat, sejahtera maju dan mandiri, kesetaraan dan keadilan gender, serta kesadaran hukum dan lingkungan. (Permendagri No. 1 tahun 2013). Melalui program DMIJ kegiatan PKK diberikan biaya pembinaan sebesar Rp. 10.000.000,- setiap tahun anggaran. Hasil keterangan (Mlan) menyebut " kegiatan PKK telah berjalan dengan baik, banyak kegiatan-kegiatan yang telah dilakukan ibuibu PKK di Desa Danau Pulai Indah salah satu contohnya kegiatan sosialisasi gizi buruk". Senada dengan pernyataan sekdes Karya tani "Kegiatan PKK untuk didesa karya tani berjalan dengan baik, Pkk memiliki program kesehatan balita, lansia Imunisasi, makanan gizi balita"

Dari kegiatan pembinaan kemasyarakatan desa yang dilaksanakan melalui program DMIJ, dapat dikatakan telah terlaksana secara baik. Salah satu aspek penting dalam pembinaan kemasyarakatan desa ialah melestarikan dan mengembangkan gotong royong masyarakat desa, masyarakat ikut terlibat dalam pembangunan desa, hal ini termasuk dalam kategori Indeks Desa Membangun (IDM) maknanya adalah bahwa pembanguunan dari dalam (berasal dari masyarakat) tidak hanya mengharapkan dana dari luar. ialah tumbuh dan berkembangnya Modal Sosial ditengah-tengah masyarakat.

\subsubsection{Pemberdayaan Masyarakat}


Pemberdayaan masyarakat Desa bertujuan memampukan Desa dalam melakukan aksi bersama sebagai suatu kesatuan tata kelola Pemerintahan Desa, kesatuan tata kelola lembaga kemasyarakatan Desa dan lembaga adat, serta kesatuan tata ekonomi dan lingkungan.

Di Desa Danau Pulai Indah kegiatan Program DMIJ dibidang pemberdayaan ialah pelatihan kepala desa, aparat desa, BPD, Posyandu, dan Pelatihan kerajinan Miniatur. Tahun 2018 anggaran dari program DMIJ untuk kegiatan pemberdayaan sebesar Rp. 69.256.980,- namun dari kegiatan tersebut tidak ada kegiatan pemberdayaan dalam mengembangkan usaha ekonomi masyarakat pertanian dan perkebunan. Data menunjukkan, mata pencaharian utama masyarakat Desa Danau Pulai Indah ialah sektor pertanian kelapa, luas perkebunan kelapa masyarakat mencapai $1.100 \mathrm{Ha}$ penduduknya berproduksi pada sektor pertanian kelapa.

Kegiatan peningkatan kapasitas masyarakat seharusnya diarahkan kepada penguatan Sumber Daya Manusia (SDM) masyarakat petani kelapa. Tidak adanya Inovasi dan kreatifitas petani kelapa menyebabkan terjadinya ketidakberdayaan masyarakat petani dalam memproduksi kelapa yang hanya di jual dalam bentuk bahan mentah yang ditampung/dibeli oleh para agen (tokeh) yang kemudian dijual pada korporasi (perusahaan) kelapa di Kabupaten Indragiri Hilir. Keterangan tokoh masyarakat (Mlan) menyebutkan 'harga kelapa selalu turun naik, tidak menentu dan harga saat ini sangat murah sekali, hanya Rp. 500-700 perbutir, sehingga masyarakat sulit memenuhi kebutuhan ekonominya."

Program DMIJ pada bidang pemberdayaan harus difokuskan pada penguatan kapasitas masyarakat petani kelapa agar mampu melahirkan produkproduk turunan dari produk kelapa tersebut. Program DMIJ dalam transformasinya menggunakan pola pendampingan. Pendampingan adalah pekerjaan yang dilakukan oleh fasilitator atau pendamping masyarakat dalam berbagai kegiatan program. Fasilitator juga seringkali disebut fasilitator masyarakat (community facilitator/CF) karena tugasnya lebih sebagai pendorong, penggerak, katalisator, motivator masyarakat, sementara pelaku dan pengelola kegiatan adalah masyarakat sendiri. (afandi, dkk. 2013). Suharto (2005,h.93) mengatakan pendampingan sebagai suatu strategi yang umum digunakan oleh pemerintah dan lembaga non profit dalam upaya meningkatkan mutu dan kualitas dari sumber daya manusia, sehingga mampu mengindentifikasikan dirinya sebagai bagian dari permasalahan yang dialami dan berupaya untuk mencari alternative pemecahan masalah yang dihadapi. Kemampuan sumber daya manusia sangat dipengaruhi oleh keberdayaan dirinya sendiri. Oleh karena itu sangat dibutuhkan kegiatan pemberdayaan disetiap kegiatan pendampingan.

Pendampingan berarti bantuan dari pihak luar, baik perorangan maupun kelompok untuk menambahkan kesadaran dalam rangka pemenuhan kebutuhan dan pemecahan permasalahan. Pendampingan diupayakan untuk menumbuhkan keberdayaan dan keswadayaan agar masyarakat yang didampingi dapat hidup secara mandiri. Jadi pendampingan merupakan kegiatan untuk membantu individu maupun kelompok yang berangkat dari kebutuhan dan kemampuan kelompok yang didampingi dengan mengembangkan proses interaksi dan komunikasi dari, oleh, dan untuk anggota, serta mengembangkan kesetiakawanan dan solidaritas kelompok dalam rangka menumbuhkembangkan kesadaran sebagai manusia yang utuh, berperan dalam kehidupan masyarakat sesuai dengan kemampuan yang dimiliki. (Mubyarto, 1984) mengatakan Pemberdayaan ekonomi masyarakat adalah upaya untuk membangun daya ekonomi masyarakat yang mendorong, motivasi, dan membangkitkan kesadaran akan potensi ekonomi yang dimiliki masyarakat serta berupaya untuk mengembangkannya yang merangkum nilai-nilai sosial. Memberdayakan masyarakat berarti upaya untuk meningkatkan harkat dan martabat lapisan masyarakat yang dalam kondisi tidak mampu melapaskan diri dari perangkap kemiskinan dan keterbelakangan. Dengan kata lain memberdayakan dalam memampukan dan memandirikan masyarakat dibidang ekonomi.

Pemberdayaan diarahkan guna meningkatkan ekonomi masyarakat secara produktif sehingga mampu menghasilkan nilai yang tinggi dan pendapatan yang lebih besar. Upaya peningkatan kemampuan untuk menghasilkan nilai tambah tidak harus ada perbaikan akses terhadap empat hal, yaitu akses sumber daya, akses terhadap teknologi, akses terhadap pasar dan akses terhadap permintaan. Pemberdayaan sosial ekonomi pada intinya dapat diupayakan melalui berbagai kegiatan antara lain pelatihan, pendampingan, penyuluhan, pendidikan dan keterlibatan organisasi demi 
menumbuhkan dan memperkuat motivasi hidup dan usaha, serta pengembangan pengetahuan, keterampilan hidup dan kerja. (Yayasan SPES, 1992)

Pendampingan pengembangan usaha ekonomi produktif merupakan tujuan program DMIJ. Di Desa Danau Pulai Indah dan Desa Karya Tani memiliki Kelembagaan Badan Usaha Milik Desa (BUMDes) sebagai lembaga ekonomi. Desa. Namun BUMDes di Danau Pulai Indah dan Desa Karya Tani tidak beroperasionalisasi secara sehat dan tidak memiliki unit-unit usaha yang sesuai dengan potensi lokal desa, dengan demikian BUMDes di Danau Pulai Indah dan Desa Karya Tani tidak berfungsi dalam menggerakkan ekonomi masyarakat. Lemahnya Sumber Daya Manusia pengelola BUMDes menyebabkan BUMDes tidak tumbuh dan berkembang melakukan kegiatan bisnis yang inovatif. BUMDes sebagai lembaga untuk menggerakkan usaha ekonomi desa menurut (Mustakim, 2015) salah satu permasalahan nya ialah kegagalan Desa dalam aspek kepemimpinan Desa. Kepala Desa sebagai pemimpin Desa tidak mempunyai imajinasi dan prakarsa yang kuat untuk menggerakkan masyarakat dan mengonsolidasikan aset ekonomi lokal. Kepala Desa ataupun Pemerintah Desa hanya disibukkan dengan mengelola bantuan dari pemerintah baik itu pusat, provinsi maupun Kabupaten Kota. Dan Seringkali bantuan yang diberikan tersebut masih belum menyentuh gerakan ekonomi lokal.

Pendamping desa, sesungguhnya mempunyai pekerjaan penting, dalam konteks implementasi Undang-undang nomor 6 tahun 2014 secara implisit memberikan amanah kepada profesi pendamping desa untuk mampu melakukan kerja-kerja pemberdayaan di masyarakat. Dengan demikian, profesi pendamping desa harus betul-betul memahami apa itu kerjakerja pemberdayaan masyarakat, bukan hanya sekedar datang ke desa satu, dua atau tiga kali dalam 1 (satu) minggunya untuk menyampaikan kepada aparat desa tentang jumlah anggaran program, petunjuk teknis pelaksanaan proyek, dan tata cara pembuatan LPJ Nya, dan setelah itu pulang.

Cakupan kegiatan pendampingan Desa yang diharapkan setidaknya menyangkut dua (2) hal, yaitu pengembangan kapasitas teknokratis dan pendidikan politik. Pengembangan Kapasitas teknokratis, mencakup pengembangan pengetahuan dan keterampilan terhadap para pelaku Desa dalam hal pengelolaan perencanaan, penganggaran, keuangan, administrasi, sistem informasi dan sebagainya. Pendidikan
Politik, terwujudnya masyarakat yang aktif, kritis, peduli, berdaulat dan bermartabat. Pendampingan ini merupakan sarana kaderisasi pada masyarakat lokal Desa agar mampu menjadi penggerak pembangunan dan demokratisasi Desa. Kaderisasi dilakukan dengan melakukan pendidikan, pelatihan dan membuka ruang-ruang publik serta akses perjuangan politik untuk kepentingan masyarakat. Politik dalam konteks ini bukan dalam pengertian perebutan kekuasaan melainkan penguatan pengetahuan dan kesadaran akan hak, kepentingan dan kekuasaan mereka, dan organisasi mereka merupakan kekuatan representasi politik untuk berkontestasi mengakses arena dan sumberdaya Desa. Pendekatan pendampingan yang berorientasi politik ini akan memperkuat kuasa rakyat sekaligus membuat sistem Desa menjadi lebih demokratis.

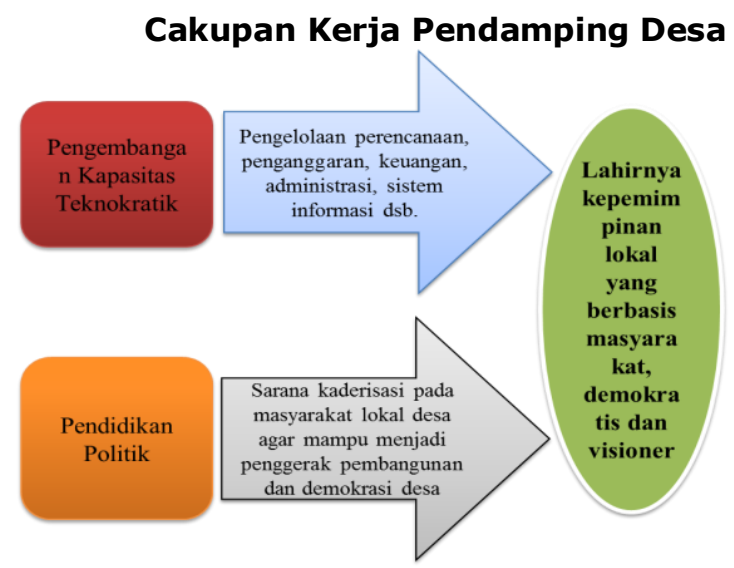

Gambar 5. Cakupan Kerja Pendamping Desa Sumber : Mustakim, 2015.

Menurut (Sutoro Eko, 2014). Pendampingan Desa diarahkan untuk mengisi "ruang-ruang kosong" baik secara vertikal maupun horizontal. Mengisi ruang kosong identik dengan membangun "jembatan sosial" (social bridging) dan "jembatan politik" (political bridging). Pada ranah Desa, ruang kosong vertikal adalah kekosongan interaksi dinamis antara warga, pemerintah Desa dan lembaga-lembaga Desa lainnya.

Program DMIJ dalam transformasinya, menggunakan tenaga sumber daya manusia yang disebut dengan pendamping desa, pendamping desa direktut untuk mendampingi implementasi program DMIJ. Keberadaan pendamping desa sangat penting dan strategis dalam rangka mewujudkan tujuan inti (ruh) program DMIJ yaitu "membangun kapasitas masyarakat 
desa untuk keluar dari rantai kemiskinan", kebijakan program DMIJ dibangun atas konsep-konsep pembangunan yang berbasis atau bertumpu pada "masyarakat". Dengan demikian, program DMIJ adalah program strategis agar terciptanya pelembangan sistem pembangunan partisipatif di pedesaan di Kabupaten Indragiri Hilir. Dari hasil temuan penelitian, menunjukkan salah satu evaluasi pelaksanaan program DMIJ yang berlangsung selama 5 (lima) tahun khususnya di Desa Nusantara Jaya pendamping desa harus lebih maksimal mentransformasikan program, kepada aparatur desa dan masyarakat dalam rangka mewujudkan gerakan sosial (social movement) menuju desa yang maju dan mandiri di Desa Nusantara Jaya dan Kabupaten Indragiri Hilir secara umum.

Desa mandiri bagaiman mewujudkannya?. Beberapa hasil penelitian mengungkapkan telah banyak desa-desa yang merintis kemandirian desa tanpa menuggu kehadiran pemerintah supradesa. Praktik inovatif dan emanstipatif yang tumbuh dari dalam desa-desa diberbagai belahan negeri Indonesia maka strategi yang ditawarkan ialah sinergisitas warga dan organisasi warga, sinergisitas organisasi warga dan pemerintah desa, menggerakkan ekonomi desa berbasis potensi dan aset lokal.

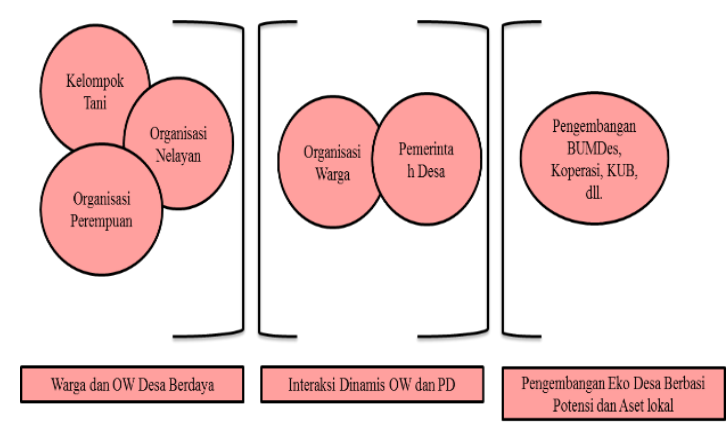

Gambar 6. Strategi Mewujudkan Desa Mandiri Dalam

Merujuk strategi tersebut, maka kebijakan Program DMIJ Plus terintegrasi tidak mungkin dapat dilaksanakan secara maksimal sendiri melalui intervensi struktural birokrasi pemerintah semata. Memanfaatkan modal sosial (social capital) yang tumbuh ditengah-tengah masyarakat hendaknya menjadi kekuatan (strenght) dalam mentransformasikan tujuan program, dan para pendamping desa harus mendorong terbentuknya sinergisitas tersebut dalam kerja-kerja pemberdayaan.

\subsection{Dampak Program DMIJ}

Penelitian yang dilakukan dengan metode pengumpulan data melalui wawancara, observasi dokumentasi dan kuesioner. Pelaksanaan program DMIJ di desa Danau Pulai Indah dan Desa Karya Tani Kecamatan Kempas berdampak bahwa:

1. Program DMIJ adanya penguatan kapasitas pemerintah desa

Dibuktikan adanya peningkatan Insentif aparatur desa, dapat dilihat dari alokasi belanja APBDesa. Sejalan dengan yang ditetapkan dalam peraturan bupati Indragiri Hilir Nomor 6 tahun 2017 pada BAB V pendanaan. Bahwa $30 \%$ APBDesa digunakan untuk penghasilan tetap kepala desa dan perangkat desa lainnya.

Program DMIJ juga terdapat kegiatankegiatan pelatihan aparatur desa yang bertujuan untuk meningkatkan kapasitas aparat desa untuk mengelola pembangunan desa.

2. Program DMIJ meningkatkan pelayanan kepada masyarakat

Konsep membangun desa sesuai dengan kebutuhan masyarakat, yang menjadi fokus program DMIJ yang dilaksanakan oleh pemerintah desa adalah pembangunan jalan dan jembatan sebagai penghubung dan untuk meningkatkan aktifitas perekonomian masyarakat, pendidikan dan juga jaminan memperoleh pelayanan kesehatan serta segala hal yang dibutuhkan masyarakat, fasilitas untuk membangun daerahnya. Melalui program DMIJ ini pemerintah lebih dekat dengan masyarakat sehingga memberikan peningkatan pelayanan kepada masyarakat

3. Munculnya Partisipasi masyarakat untuk membangun desa

Tujuan khusus dari program DMIJ adalah mendorong masyarakat untuk ikut berperan aktif membangun desa menjadi desa yang mandiri dan maju. Pembangunan tidak lagi peran pemerintah desa semata, tetapi membangkitkan kembali kebersamaan dan semangat gotong royong ditengahtengah masyarakat. Hasil penelitian juga menunjukan bahwa dikedua desa (Danau Pulai Indah dan Karya Tani) tumbuh dan berkembang rasa solidaritas dan semangat swadaya masyarakat untuk membangun desa.

4. Meningkatkan perekonomian desa, dikedua desa (Danau Pulai Indah dan Karya Tani), hasil penelitian, menunjukkan tidak tampak secara 
maksimal dalam hal permberdayaan ekonomi masyarakat, karena kegiatankegiatan program DMIJ belum menyentuh kepada peningkatan perekonomian masyarakat desa, potensi perekonomian dua desa (Danau Pulai Indah dan Karya Tani), sangat besar dibidang pertanian dan perkebunan, namun program DMIJ belum maksimal melaksanakan program pemberdayaan masyarakat desa, sehingga masyarakat monoton dan tidak mampu melakukan Inovasi terhadap potensi yang dimiliki.

5. Program Pembinaan masyarakat desa juga sudah berdampak positif dan dirasakan masyarakat, namun baru pada bidang pendidikan keagamaan bagi anakanak. Dibuktikan dengan adanya kegiatan maghrib mengaji, dan tersedianya prasarana rumah tahfiz di dua desa tersebut.

\subsection{Kendala Pelaksanaan Program DMIJ \\ Terdapat beberapa kendala dalam} program pemberdayaan masyarakat di desa Danau Pulai Indah Dan Desa Karya Tani:

1. Dari sisi masyarakat, masih belum sepenuhnya muncul partisipasi dalam bentuk kesukarelaan dan keswadayaan untuk terlibat dalam semua proses tahapan kegiatan DMIJ. Partisipasi masyarakat, masih dalam bentuk mobilisasi.

2. Dari sisi, implementor operasionalisasi kebijakan pada tingkat desaa, masih terlihat lemahnya atau kurangnya kualitas sumber daya Manusia aparatur dalam memahami ruh pembangunan dan pemberdayaan dalam grand desain program DMIJ/plus terintegrasi, sehingga ini memunculkan hambatan dalam pelaksanaan program DMIJ untuk mencapai maksud, sasaran dan tujuan program yang diharapkan.

3. Kebijakan Program DMIJ, transformasinya dilakukan melalui pendekatan pendampingan (fasilitator), dalam penelitian ini, masih terlihat peranan dan fungsi pendamping desa belum sepenuhnya berjalan atau kurang maksimalnya kerja-kerja fasilitasi dalam konteks pemberdayaan masyarakat. Sehingga, transformasi program DMIJ dalam operasionalisasinya masih terkesan apa adanya sesuai prosedur administratif (Juknis), dan belum menyentuh pada pengisian ruang-ruang kosong ditengah masyarakat, baik secara vertikal maupun horizontal, menggali potensi-potensi desa, yang bermuara pada lahirnya inovasi produk-produk unggulan desa.

4. Program DMIJ Plus terintegrasi. Pada prakteknya belum sepenuhnya dilakukan secara lintas sektoral oleh dinas dan instansi dalam melakukan melakukan program.

\section{Kesimpulan dan Saran}

5.1 Pelaksanaan program Desa Maju Inhil Jaya Plus teritegrasi di Desa Danau Pulai Indah dan Desa Karya Tani mencakup 4 (empat) bidang kegiatan, yaitu kegiatan penyelenggaraan pemerintahan desa, pembangunan desa, kemasyarakata desa, pemberdayaan masyarakat desa. Pelaksanaan kegiatan belum sepenuhnya terlaksana dengan baik, kegiatan program yang dijalankan tidak semuanya sesuai dengan item-item kegiatan, sesuai dengan petunjuk pelaksanaan program DMIJ dan tujuan khusus dari program DMIJ.

5.2 Pelaksanaan program masih bersifat konservatif-involutif artinya para pelaku program; kepala desa, aparat desa, pendamping desa masih bekerja apa adanya (taken for granted), melaksanakan fungsi secara tekstual sesuai tugas pokok dan fungsi ( tupoksi) merealisasikan anggaran sesuai prosedur target dan realisasi anggaran. Belum tampak adanya upaya melakukan Inovasi (perubahan) yang mengarah kepada pencapaian perubahan status desa dari tertinggal menjadi desa maju dan mandiri.

5.3 Program DMIJ yang telah dijalankan selama 5 (lima) tahun di Desa Danau Pulai Indah dan desa Karya Tani baru berdampak positif pada bidang penyelenggaraan pemerintahan dan bidang pembangunan desa. yakni adanya alokasi penguatan dana operasional pemerintah desa dan insentif aparat penyelenggaraan pemerintah desa, dan pembangunan desa juga memadai dalam pembangunan Infrastruktur seperti jalan dan jembatan. Pada, bidang pembinaan kemasyarakata desa juga dapat dikatakan baik. Namun pada bidang pemberdayaan masyarakat desa, hasil yang diinginkan belum tercapai secara baik atau kurang maksimal.

5.4 Dampak dari program DMIJ belum sepenuhnya dirasakan masyarakat, kontribusi program masih minim dalam bidang pemberdayaan masyarakat, program DMIJ belum mengarah kepada 
memecahkan masalah ditengah-tengah masyarakat. khususnya dalam aspek pergerakan ekonomi masyarakat, dalam pengembangan sarana ekonomi produktif masyarakat pada sektor pertanian dan perkebunan, dan peningkatan kapasitas masyarakat.

5.5 Kendala dalam pelaksanaan transformasi program DMIJ dalam upaya pemberdayaan masyarakat secara khusus dapat disimpulkan pada, pada masih minimnya atau kurangnya kualitas sumberdaya manusia, pada sisi masyarakat sebagai subjek maupun objek program DMIJ, aparatur desa selaku pelaksana pemberdayaan pada tingkat desa, pendamping (fasilitator) yang belum maksimal melakukan kerjakerja pendampingan dalam konteks pemberdayaan masyarakat. Dan program DMIJ plus terintegrasi pada opersionalisasinya belum menjadi payung sentral program-program lintas sektoral.

Sebagai saran penulis dalam penelitian evaluasi program DMIJ ialah :

1. Pemerintah Daerah melalui dinas terkait sebaiknya merumuskan indikatorindikator pencapaian atau kriteria sukses program DMIJ Plus terintegrasi menuju perubahan status desa maju dan mandiri.

2. Pemerintah Daerah melalui dinas, instansi terkait (lintas sektoral) sebaiknya lebih memaksimal sinergisitas, bekerjasama melakukan program-program yang dibutuhkan desa untuk mencapai tujuan DMIJ.

3. Melakukan penguatan sumber daya manusia pelaku program DMIJ dalam konteks pemahaman esensi dan ruh pemberdayaan masyarakat.

4. Memaksimalkan peranan pendamping desa dalam mentransformasikan tujuan program dalam kerja-kerja pemberdayaan masyarakat.

5. Program DMIJ menjadi pendorong pergerakan ekonomi rakyat, dengan memgembangkan sarana ekonomi produktif sesuai dengan potensi desa, adanya inventarisasi aset-aset desa dan dekelola melalui BUMDes yang telah terbentuk, penguatan kapasitas masyarakat sebaiknya menjadi fokus dalam transformasi program DMIJ Plus terintegrasi. Keluaran program DMIJ ditekankan melahirkan satu produk unggulan desa (one village one product).

\section{Daftar Pustaka}

[1] Afandi, Agus dkk. 2013. Modul Participatory Action Research (PAR), Surabaya: LPM IAIN Sunan Ampel.

[2] Arif Muhammad, Suci Lestari Shinta, 2017. Analisisis Implementasi Program Pemberdayaan Masyarakat (Community Empowerment) Studi Kasus pada Program Desa Maju Inhil Jaya di Kabupaten Indragiri Hilir. http://jurnal.univrab.ac.id Vol 4 No 1 (2018): Juni.

[3] Arikunto Suharsimi, 2013. Prosedur Penelitian Suatu Pendekatan Praktik, Jakarta: Rineka Cipta

[4] Beratha, I Nyoman. 1991. Pembangunan Desa Berwawasan Lingkungan. Jakarta :Bumi Aksara.

[5] Batten, T.R. 1957. Communities and Their Development. London: Oxford University Press.

[6] Badan Pusat Statistik Kabupaten Indragiri Hilir Tahun 2007

[7] Eko Sutoro, 2015. Regulasi Baru, Desa Baru, Ide, Misi, dan Semangat UU Desa Jakarta: Kementerian Desa Pembangunan Daerah Tertinggal, Dan transmigrasi Republik Indonesia.

[8] Hamidi Hanibal, Nugroho Setijonegoro, Fujitriartanto, Armen Sa'id, Harioso, Huda, Andik Hardiyanto, Bambang Waluyanto, Indra Gunawan, Dani Setiawan. Hadi Prayitno, Ana Fitrotul, 2015. Indeks Desa Membangun 2015. Jakarta: Kementerian Desa, Pembangunan Daerah Tertinggal, dan Transmigrasi Republik Indonesia.

[9] Kurniawan Borni, 2015. Buku 5 Desa Mandiri, Desa Membangun Jakarta: Kementerian Desa Pembangunan Daerah Tertinggal, Dan transmigrasi Republik Indonesia.

[10] Kartasasmita, Ginanjar. 1996. Pembangunan Untuk Rakyat, Memadukan Pertumbuhan dan Pemerataan. CIDES, Jakarta

[11] Kessa Wahyudin, 2015. Buku 6 Perencanaan Pembangunan Desa, Jakarta: Kementerian Desa Pembangunan Daerah Tertinggal, Dan transmigrasi Republik Indonesia.

[12] Kasimin hamsiah, 1996. Program Pembangunan Rakyat Termiskin (PRRT) yang Bersepadu : Satu Analisis Daripada Pandangan Pengurusan Sibernitiks. Dalam Chamsuri Siwar dan Nor Aini $\mathrm{Hj}$. Idrin (pynt). Kemiskinan Dalam Arus Pembangunan Ekonomi 
Malaysia. Bangi: Penerbit University Kebangsaan Malaysia.

[13] Mustakim Mochammad Zain, 2015. Buku 2 Kepemimpinan Desa, Kementerian Desa, Pembangunan Daerah Tertinggal, Dan Transmigrasi Republik Indonesia Jakarta.

[14] Mubyarto, $1984 . \quad$ Pembangunan Pedesaan. P3PK UGM, Yogyakarta

[15] M, Silahuddin, 2015. Buku 1 Kewenangan Desa Dan Regulasi Desa, Jakarta: Kementerian Desa Pembangunan Daerah Tertinggal, Dan transmigrasi Republik Indonesia.

[16] Mupid Mohd. Sukran, Partisipasi Masyarakat Dalam Pelaksanaan Program Desa Maju. Jurnal Ilmu Administrasi Negara, Volume 14, Nomor 1, Juli 2016 : 85-89. Fisipol Universitas Riau: Pekanbaru

[17] Nurcholis, Hanif. 2011. Pertumbuhan \& Penyelenggaraan Pemerintahan Desa. Erlangga, Jakarta

[18] Narbuko Cholid \& Achmadi Abu, 2008. Metodologi Penelitian, Bumi Aksara. Jakarta.

[19] Rostika Diden, 2003. Pemberdayaan Masyarakat Miskin Melalui Program Pengembangan Kecamatan (PPK). Studi Kasus di Desa Margaluyu Kecamatan Tanjungsari Kabupaten Sumedang. Tesis Megister Sains Jurusan Kesejahteraan Sosial. Perpustakaan Pusat Universitas Indonesia. Jakarta.

[20] Suharto, Edi. 2009. Membangun Masyarakat Memberdayakan Masyarakat, PT Refika Aditama, Bandung

[21] Soemodiningrat, Gunawan. 1997. Membangun Perekonomian Rakyat, IDEA

[22] Sugiyono, 2012. Metode Penelitian Kuantitatif, Kualitatif dan RD. Alfabeta, Bandung.

[23] Subarsono, 2006. Analisis Kebijakan Publik Konsep, Teori dan Aplikasi. Pustaka Pelajar, Jakarta.

[24] Salisusiana \& Yulia, 2000. Pembangunan Sosial Teori dan Implikasi Kebijakan. Pusat Pengkajian dan Pelayanan Informasi Sekretariat Jenderal DPR RI, 2000. Jakarta.

[25] Shari Ishak, 2000. Pembangunan dan Ketidaksetaraan Pendapatan: Pencapaian dan Cabaran Masa Depan. Dalam Abdul Rahman Embong (pnyt). Negara Pasaran dan Pemodenan Malaysia. Bangi: Penerbit University Kebangsaaan Malaysia.
[26] Yayasan SPES, Pengembangan Berkelanjutan, (Jakarta: PT Pustaka, Pustaka Utama, 1992)

\section{Peraturan Perundang-undangan:}

[27] Undang - Undang Republik Indonesia Nomor 6 Tahun 2014 Tentang Desa. 15 Januari 2014. Lembaran Negara Republik Indonesia Tahun 2014 Nomor 7. Jakarta.

[28] Peraturan Menteri Desa, Pembangunan Daerah Tertinggal, Dan Transmigrasi Republik Indonesia Nomor 2 Tahun 2016 Tentang Indeks Desa Membangun.18 Februari 2016. Berita Negara Republik Indonesia Tahun 2016 Nomor 300. Jakarta.

[29] Peraturan Daerah Kabupaten Indragiri Hilir Nomor 5 Tahun 2015 Tentang Desa Maju Inhil Jaya

[30] Pemerintah Kabupaten Indragiri Hilir; Petunjuk Teknis Operasional Program Maju Inhil Jaya Tahun 2016

[31] Pemerintah Kabupaten Indragiri Hilir, Petunjuk Teknis Operasional Program Desa Maju Inhil Jaya Tahun 2017 